\title{
Seroprevalence of transfusion-transmissible infectious agents (HIV, HBV, HCV, plasmodium species and treponema pallidum infections) among blood donors at a Tertiary Care Teaching Hospital in Chennai: Changing trends over a period of five years
}

\author{
D. Umesh ${ }^{1, *}$, Aparna V. ${ }^{2}$, S. Padma ${ }^{3}$ \\ ${ }^{\mathbf{1}}$ Assistant Professor, ${ }^{\mathbf{2}} \mathrm{PG}$ Student, ${ }^{\mathbf{3}}$ Tutor, ${ }^{\mathbf{1 , 3}}$ Dept. of Transfusion Medicine \& Blood Bank, ${ }^{\mathbf{2} D e p t . ~ o f ~ P a t h o l o g y, ~ R a j i v ~ G a n d h i ~}$ \\ Government General Hospital \& Madras Medical College, The Tamilnadu Dr. M. G. R. Medical University, Chennai, Tamil \\ Nadu, India
}

*Corresponding Author:

Email: dr.umesh77@gmail.com

\begin{abstract}
Introduction: Transfusion-transmissible infections (TTI) are principal threat to the recipient of a blood transfusion. Consequently, Drugs and cosmetics act asserts that mandatory screening tests must be performed to rule out TTI (human immunodeficiency virus (HIV), hepatitis B virus (HBV), hepatitis C virus (HCV), Plasmodium species and Treponema pallidum). The principal intention of this study was to resolve the seroprevalence and inclining trends of TTI amongst blood donors at a tertiary care teaching hospital in Chennai.

Materials \& Methods: A detailed retrospective study and analysis of successive blood donors'(both voluntary and replacement) records covering over the period from January 2010 and December 2014 was carried out. Statistical analysis was performed to establish the trends interconnected with TTI.

Results: 2006 (1.2\%) donor blood samples from 165809 successive blood donors were tested to be serologically reactive for at least one infectious agent, amongst which $14(0.008 \%)$ samples tested contained more than one TTI agents. Correspondingly, on the whole seroprevalence of TTI agents - HIV, HBV, HCV, Plasmodium sp. and Treponema pallidum infections was $0.04 \%$, $1.14 \%, 0.022 \%, 0.0006$ and $0.0006 \%$. A statistical significant correlation was identified between HBV and HIV viral infections. Furthermore, appreciably declining tendency in seropositivity of HIV, Plasmodium sp. and Treponema infections and continuing increasing drift of perilous HBV and HCV sero-reactivity was identified throughout the study phase.

Conclusion: A considerably significant fraction pool of blood donations spread $H I V, H B V$ and $H C V$ infections. Compulsory screening of donors' blood with stringent selection of voluntary blood donors along with by prescribed standard techniques are particularly recommended to guarantee the protection of recipient undergoing blood transfusion.
\end{abstract}

Keywords: Drugs and cosmetics act 1940, Mandatory screening test, Seroprevalence, Transfusion-Transmissible Infectious (TTI) Agents.

\section{Introduction}

Blood banking services form an indispensable part of the Health Services in a nation. With increasing demand for blood products associated with increasing Transfusion-transmissible infections (TTI) amid remarkable progress in transfusion technology had made regularising agencies to make obligatory regulations to assure safe, potent, effective and quality blood components for the recipient. Director General of Health Services along with Drugs Controller General of India carried out amendments with modifications periodically in the Drugs and Cosmetic Act, 1940 to warranty quality assurance systems for better and safe blood transfusion services. ${ }^{1}$

Transfusion of blood products even though beneficial to the patient has its own hazards. The most dangerous risk is the TTI. ${ }^{2}$ The mandatory screening for TTIs on blood donors have started a bright future for health services thereby providing safe transfusion. . $^{1,3,4}$

As per Drugs and cosmetics act ${ }^{3}$, the mandatory screening tests on donated blood units in India are:

1. Surface antigen of Hepatitis B virus

2. Screen for antibodies to glycoprotein of $H I V-1 \& 2$
3. Antibodies against Hepatitis C virus (Anti HCV)

4. Antibody to Treponema pallidum (Syphilis), and

5. Malarial organism

There is always a question related to the safety associated with blood transfusion in India where adequate financial resources, trained personnel, good infrastructure along with the best national blood policy is present but the blood transfusion services are not vigilantly monitored as hemovigilance programme of India is in the initial stages of implementation. ${ }^{5}$

Among the Asian countries, a well established hemovigilance system is lacking and there is paucity of data on hemovigilance except for Japan, which has published report on adverse transfusion reactions and infectious diseases. ${ }^{6,7}$

Viral infections such as $H I V, H B V$ and $H C V$ cause big anxiety due to protracted viraemia along with carrier / latent state. Transfusion of blood components contribute up to $1 \%$ to the $H I V$ transmission among the individuals in India. ${ }^{8}$ Due to the currently prevalent stringent screening practices, the percentage of $H I V$ cases attributable to blood transfusion has decreased considerably from $8 \%$ in mid-nineties to $1 \%$ in $2009 .{ }^{9}$ 
Hepatitis is one of the public health hazards worldwide today. ${ }^{10,11} \mathrm{~A}$ study by Patwari et al reported higher incidence of $H B V$-carrier state in transfusion recipients as compared to the general population (12.3\% vs. 3.6\%) and found the incidence of TAH-B (transfusion associated hepatitis $B$ ) to be $11 \% .^{12}$ Likewise, $12.3 \%$ of patients are at risk of post transfusion hepatitis due to blood transfusion. ${ }^{13}$

Hepatitis $C$ virus can cause post-transfusion liver inflammation and injury. ${ }^{1,6}$ Till date, there is no preventable vaccine for $H C V$ virus, and also drug treatment and interferon therapy for $\mathrm{HCV}$ infection is expensive. ${ }^{11,12}$

Treponema pallidum can spread through blood component transfusion even though Syphilis can also spread by sexual actions and by means of vertical transmission. ${ }^{14,15}$ T.pallidum can be transmitted by fresh blood and in exchange transfusion of blood in newborns. It is not transmitted by plasma products fractionated from pooled plasma such as Factor VIII. It is usually not transmitted by stored blood as refrigeration at $4^{\circ} \mathrm{c}$ inactivates the organism within 72 hours. ${ }^{1}$

Malaria transmitted through blood Transfusion (TTM) is most commonly caused by $P$. falciparum followed by $P$. vivax and $P$. malaria .Transmission of malaria has been reported to occur mainly from whole blood and from packed red blood cell concentrate. ${ }^{16-21}$

The seroprevalence of TTI in blood donor population has raised the troubles associated with protection of blood product transfusion in India. Hence, there is a need for uninterrupted inspection of TTI in blood donors to estimate the perils of blood component transfusion. Based on the above criteria, the present study was carried on to resolve and establish the seroprevalence and ongoing trends of TTI ( $H I V, H B V$, $H C V$, malaria and syphilis) amid blood donors at a tertiary care medical college teaching hospital in Chennai.

\section{Materials and Methods}

A detailed retrospective analysis of successive voluntary and replacement blood donors' records over the period from January 2010 and December 2014 was conducted at a tertiary care medical college teaching hospital in Chennai. The group of blood donors was either voluntary blood donors, or replacement donors (friends/relations of recipients'). TANSACS self questionnaire was filled by Potential blood donors. NACO criteria were used to screen the blood donors. The details of the donor were filled in the donor logbook. After taking sterile precautions, venous phlebotomy was performed and blood was collected in sterile blood collection bags. ABO Blood grouping and $\mathrm{Rh}$ typing was performed on all donors.
Laboratory diagnostic tests for identifying antibodies to glycoprotein of $H I V I \& 2$ : NACO supplied ELISA kit with reported sensitivity \& specificity of $100 \%$ \& $99.34 \%$ respectively were used in identifying antibodies to glycoprotein of $H I V 1 \& 2$ in donor's serum/plasma.

Screening kit tests for $H B s A g$ and antibodies to $H C V$ (NACO supplied kit): ELISA kit with reported sensitivity \& specificity of $100 \%$ \& $99.9 \%$ respectively were used in identifying hepatitis $B$ surface antigen in donor's serum/plasma. Likewise, antibodies to $H C V$ antigens for core, NS3, NS4 and NS5 were detected using ELISA technique with reported sensitivity of $100 \%$ and specificity of $99.02 \%$.

All serologically reactive and grey zone samples were tested again using the same ELISA kit as well as a rapid test kit based on the principle of a one-step immunoassay. Samples showing repeat test reactivity on both methods were considered positive and were included for calculation of seroprevalence.

Laboratory diagnosis for Treponema pallidum (syphilis): Rapid plasma reagin test (RPR Test kit) was used to find for the existence of regain ( $\operatorname{IgM}$ and $\operatorname{IgG}$ ) antibodies in donor's serum/plasma.

Laboratory tests for Plasmodium Species (Malaria): Blood samples were tested for malarial parasites by blood smear (thick smear and thin smear).

\section{Statistical analysis}

Information was collected in a structured proforma. Data was entered in MS Office Excel format. SPSS software (version 20) was used for statistical analysis of the collected variables. Variation in the seroprevalence of TTI and Socio-demographic variables were investigated for significance using logistic regression. Linear regression was performed to evaluate the statistical significance of trends in seroprevalence of these TTI agents over the study period.

\section{Results}

165809 successive blood donors were screened at the blood bank of a medical college teaching hospital throughout the study period. Table no.1 shows the socio-demographic characteristics of blood donors and Table 2 shows the prevalence of blood donors according to blood groups. Among the study group, $92712(55.91 \%)$ were in the age group of $18-25$ years, 104459 (62.99\%) were first time blood donors, 64997 (39.19\%) were O blood group and 154497 (93.18\%) were Rhesus $\mathrm{D}(\mathrm{Rh})$ positive donors. In addition, College/University students (32.2\%), corporate company staff $(31.7 \%)$ and daily laborers (23.3\%) constituted a major portion of the blood donors. 


\section{Seroprevalence of TTI}

In general, the seroprevalence rate of TTI- HIV, HBV, HCV, Plasmodium species and Treponema pallidum was $0.04 \%, 1.14 \%, 0.022 \%, 0.0006 \%$ and $0.0006 \%$ respectively as shown in Table no.3. 2006 (1.2\%) donor blood samples from 165809 successive blood donors were tested to be serologically reactive for at least one infectious agent, amongst which 14 $(0.008 \%)$ samples tested contained more than one TTI agents. The most frequent combinations amongst the donors with multiple TTI infections were $H I V$ - $H B V$ (42.85\%) followed by $H C V-H B V(28.58 \%), H I V$ $H C V(21.43 \%)$ and HIV-Syphilis $(7.14 \%)$ which are shown in Table 4. The seroprevalence of HIV virus was greatly increased amongst male blood donors in comparison to female blood donors, first time donors in comparison to repeat donors, and drivers and construction workers in comparison to students as shown in Table 5, but all the above comparisons were not statistically significant $(\mathrm{p}>0.05)$. The seroprevalence of $H C V$ was seriously increased amid daily laborers and construction workers in comparison to students but the above was not statistically significant. Statistical significant $(\mathrm{P}<0.05)$ increase in seroreactivity of $H B V$ was seen amongst donors with the age groups $36-45$ years and more than 45 years in comparison to the age group 26-35 years, daily laborers in comparison to students and first time donors in comparison to repeat donors.

\section{Trends of TTI Seroprevalence}

There was a notable significant waning trend of HIV $(\mathrm{P}=0.038)$ during the phase of study. Seroprevalence of $H I V$ virus which was recorded as $0.08 \%$ in 2010 decreased gradually to $0.02 \%$ in 2014 . The seroprevalence of $H B V$ virus which was recorded as $1.27 \%$ in 2010 had increased to $1.49 \%$ in 2013 and gradually decreased to $1.39 \%$ in 2014 . $H C V$ prevalence which was recorded as $0.012 \%$ in 2010 had progressively increased to $0.044 \%$ in 2013 and gradually decreased to $0.014 \%$ in 2014 . The trend in $H B V(\mathrm{p}=0.063)$ and $H C V(\mathrm{p}=0.059)$ infection in donors was on a gradual increasing trend but the decrease in number of donors with $H B V$ and $H C V$ viral infection in 2014 was not statistically significant. There was only one donor with Plasmodium infection and Treponema pallidum infection each which could not be statistically evaluated for trend and drift.

Table 1: Socio-demographic characteristics of blood donors at a tertiary care teaching hospital in Chennai from January 2010 and December 2014

\begin{tabular}{|l|c|c|}
\hline \multicolumn{1}{|c|}{ Characteristics } & Number (No.) & Percentage (\%) \\
\hline Age group(yrs) & & 55.91 \\
\hline $18-25$ & 92712 & 30.03 \\
\hline $26-35$ & 49793 & 8.87 \\
\hline $36-45$ & 14712 & 4.89 \\
\hline $46-55$ & 8114 & 0.29 \\
\hline $56-65$ & & \\
\hline Gender & 130962 & 78.98 \\
\hline Male & 34847 & 21.02 \\
\hline Female & & \\
\hline Occupation & 53391 & 32.2 \\
\hline College Student & 52562 & 31.7 \\
\hline Corporate staff & 38634 & 23.3 \\
\hline Daily laborer & 1493 & 0.9 \\
\hline Housewife & 4313 & 2.6 \\
\hline Govt employee & 6964 & 4.2 \\
\hline Merchant & 2483 & 1.5 \\
\hline $\begin{array}{l}\text { Defence and police } \\
\text { personnel }\end{array}$ & & 1.2 \\
\hline Driver & 1989 & 1.9 \\
\hline Construction workers & 3151 & 0.5 \\
\hline Others & 829 & 62.99 \\
\hline No. of donation & & 37.0 \\
\hline First donation & 104459 & \\
\hline Repeat donation & 61350 & \\
\hline
\end{tabular}


Table 2: Prevalence of Blood donors according to blood groups

\begin{tabular}{|l|c|c|}
\hline ABO Blood groups & Number (No.) & Percentage (\%) \\
\hline $\mathrm{O}$ & 64997 & 39.19 \\
\hline $\mathrm{A}$ & 35157 & 21.20 \\
\hline $\mathrm{B}$ & 53721 & 32.39 \\
\hline $\mathrm{AB}$ & 11927 & 7.19 \\
\hline Oh (Bombay group) & 7 & 0.004 \\
\hline Rhesus $($ Rh) type & & \\
\hline Positive & 154497 & 93.18 \\
\hline Negative & 11312 & 6.82 \\
\hline
\end{tabular}

Table 3: Changing Trends of seropositivity of TTI amongst blood donors at a tertiary care teaching hospital in Chennai from January 2010 and December 2014

\begin{tabular}{|c|c|c|c|c|c|c|c|}
\hline Year & 2010 & 2011 & 2012 & 2013 & 2014 & Total & \multirow{2}{*}{$\begin{array}{l}\text { p-value of linear } \\
\text { regression for } \\
\text { trend }\end{array}$} \\
\hline $\begin{array}{l}\text { Total blood } \\
\text { donors }\end{array}$ & 32069 & 34413 & 31781 & 33656 & 33890 & 165809 & \\
\hline HIV (No.) & 26 & 7 & 19 & 8 & 7 & 67 & \multirow[b]{2}{*}{0.038} \\
\hline$H I V(\%)$ & 0.080 & 0.020 & 0.059 & 0.023 & 0.020 & 0.04 & \\
\hline$H B V(N o)$. & 407 & 59 & 461 & 502 & 471 & 1900 & \multirow[b]{2}{*}{0.063} \\
\hline$H B V(\%)$ & 1.27 & 0.17 & 1.45 & 1.49 & 1.39 & 1.14 & \\
\hline $\mathrm{HCV}(\mathrm{No})$. & 4 & 1 & 12 & 15 & 5 & 37 & \multirow[b]{2}{*}{0.059} \\
\hline $\mathrm{HCV}(\%)$ & 0.012 & 0.003 & 0.037 & 0.044 & 0.014 & 0.022 & \\
\hline Plas.Sps.(No.) & 0 & 1 & 0 & 0 & 0 & 1 & \multirow[b]{2}{*}{------- } \\
\hline Plas.Sps.(\%) & 0 & 0.003 & 0 & 0 & 0 & 0.006 & \\
\hline Trep.pal (No.) & 0 & 0 & 0 & 1 & 0 & 1 & \multirow[b]{2}{*}{-------- } \\
\hline Trep.pal. (\%) & 0 & 0 & 0 & 0.003 & 0 & 0.006 & \\
\hline
\end{tabular}

$\mathrm{P}<0.05$ is significant for declining drift \& trend

Table 4: Prevalence of co-infections of TTI amongst blood donors at a tertiary care medical college teaching hospital in Chennai from January 2010 and December 2014

\begin{tabular}{|l|c|c|}
\hline \multicolumn{1}{|c|}{ Co-Infections (TTI agents) } & Number (No.) & Percentage (\%) \\
\hline$H I V-S y p h i l i s$ & 1 & 7.14 \\
\hline$H I V-H B V$ & 6 & 42.85 \\
\hline$H I V-H C V$ & 3 & 21.43 \\
\hline$H B V-$ Syphilis & 0 & 0 \\
\hline$H B V-H C V$ & 4 & 28.58 \\
\hline Syphilis- $H C V$ & 0 & 0 \\
\hline Total & 14 & 100 \\
\hline
\end{tabular}

Table 5: Socio-demographic characteristics of blood donors by $H I V, H B V \& H C V$ sero positivity at a tertiary care teaching hospital in Chennai from January 2010 and December 2014

\begin{tabular}{|c|c|c|c|c|c|c|}
\hline Characteristics & $\begin{array}{l}\text { HIV reactive } \\
(n=67)\end{array}$ & $\begin{array}{c}\text { P - } \\
\text { value }\end{array}$ & $\begin{array}{c}\text { HBV } \\
\text { reactive } \\
(n=1900)\end{array}$ & $\begin{array}{c}P \text { - } \\
\text { value }\end{array}$ & $\begin{array}{c}\text { HCV } \\
\text { reactive } \\
(\mathbf{n}=37)\end{array}$ & $\begin{array}{c}\mathrm{P} \text { - } \\
\text { value }\end{array}$ \\
\hline Age group (yrs) & $\mathrm{N}(\%)$ & & $\mathrm{N}(\%)$ & & $\mathrm{N}(\%)$ & \\
\hline $18-25$ & $\begin{array}{l}1 / 92712 \\
(0.001 \%)\end{array}$ & $>0.05$ & $\begin{array}{l}36 / 92712 \\
(0.038 \%)\end{array}$ & $>0.05$ & $\begin{array}{l}3 / 92712 \\
(0.003 \%)\end{array}$ & $>0.05$ \\
\hline $26-35$ & $\begin{array}{l}23 / 49793 \\
(0.058 \%)\end{array}$ & $>0.05$ & $\begin{array}{l}319 / 49793 \\
(0.64 \%)\end{array}$ & $>0.05$ & $\begin{array}{l}18 / 49793 \\
(0.036 \%)\end{array}$ & $>0.05$ \\
\hline $36-45$ & $\begin{array}{l}31 / 14712 \\
(0.21 \%)\end{array}$ & $>0.05$ & $\begin{array}{l}1271 / 14712 \\
(8.63 \%)\end{array}$ & $<0.05$ & $\begin{array}{l}12 / 14712 \\
(0.08 \%)\end{array}$ & $>0.05$ \\
\hline$>45$ & $\begin{array}{l}12 / 8592 \\
(0.139 \%)\end{array}$ & $>0.05$ & $\begin{array}{l}274 / 8592 \\
(3.1 \%)\end{array}$ & $<0.05$ & $\begin{array}{l}4 / 8592 \\
(0.046 \%)\end{array}$ & $>0.05$ \\
\hline \multicolumn{7}{|l|}{ Gender } \\
\hline Male & $\begin{array}{l}67 / 130962 \\
(0.05 \%)\end{array}$ & $>0.05$ & $\begin{array}{l}1896 / 13096 \\
2\end{array}$ & $<0.05$ & $\begin{array}{l}36 / 13096 \\
2\end{array}$ & $>0.05$ \\
\hline
\end{tabular}




\begin{tabular}{|c|c|c|c|c|c|c|}
\hline & & & $(1.45 \%)$ & & $(0.027 \%)$ & \\
\hline Female & $\begin{array}{l}0 / 34847 \\
(0 \%)\end{array}$ & --- & $\begin{array}{l}4 / 34847 \\
(0.011 \%)\end{array}$ & $>0.05$ & $\begin{array}{l}1 / 34847 \\
(0.002 \%)\end{array}$ & $>0.05$ \\
\hline \multicolumn{7}{|l|}{ Occupation } \\
\hline Student & $\begin{array}{l}0 / 53391 \\
(0 \%)\end{array}$ & --- & $\begin{array}{l}2 / 53391 \\
(0.003 \%)\end{array}$ & $>0.05$ & $\begin{array}{l}1 / 53391 \\
(0.001 \%)\end{array}$ & $>0.05$ \\
\hline Corporate staff & $\begin{array}{l}1 / 52562 \\
(0.001 \%)\end{array}$ & $>0.05$ & $\begin{array}{l}529 / 52562 \\
(1.01 \%)\end{array}$ & $>0.05$ & $\begin{array}{l}2 / 52562 \\
(0.003 \%)\end{array}$ & $>0.05$ \\
\hline Daily laborer & $\begin{array}{l}42 / 38634 \\
(0.11 \%)\end{array}$ & $>0.05$ & $\begin{array}{l}1174 / 38634 \\
(3.04 \%)\end{array}$ & $<0.05$ & $\begin{array}{l}19 / 38634 \\
(0.49 \%)\end{array}$ & $>0.05$ \\
\hline Housewife & $\begin{array}{l}0 / 1493 \\
(0 \%)\end{array}$ & --- & $\begin{array}{l}1 / 1493 \\
(0.067 \%)\end{array}$ & $>0.05$ & $\begin{array}{l}0 / 1493 \\
(0 \%)\end{array}$ & --- \\
\hline Govt employee & $\begin{array}{l}0 / 4313 \\
(0 \%)\end{array}$ & --- & $\begin{array}{l}2 / 4313 \\
(0.046 \%)\end{array}$ & $>0.05$ & $\begin{array}{l}0 / 4313 \\
(0 \%)\end{array}$ & --- \\
\hline Merchant & $\begin{array}{l}1 / 6964 \\
(0.01 \%)\end{array}$ & $>0.05$ & $\begin{array}{l}17 / 6964 \\
(0.24 \%)\end{array}$ & $>0.05$ & $\begin{array}{l}3 / 6964 \\
(0.04 \%)\end{array}$ & $>0.05$ \\
\hline $\begin{array}{l}\text { Defence and } \\
\text { police } \\
\text { personnel }\end{array}$ & $\begin{array}{l}0 / 2483 \\
(0 \%)\end{array}$ & --- & $\begin{array}{l}0 / 2483 \\
(0 \%)\end{array}$ & $>0.05$ & $\begin{array}{l}0 / 2483 \\
(0 \%)\end{array}$ & --- \\
\hline Driver & $\begin{array}{l}7 / 1989 \\
(0.35 \%)\end{array}$ & $>0.05$ & $\begin{array}{l}61 / 1989 \\
(3.06 \%)\end{array}$ & $<0.05$ & $\begin{array}{l}5 / 1989 \\
(0.25 \%)\end{array}$ & $>0.05$ \\
\hline $\begin{array}{l}\text { Construction } \\
\text { workers }\end{array}$ & $\begin{array}{l}16 / 3151 \\
(0.5 \%) \\
\end{array}$ & $>0.05$ & $\begin{array}{l}114 / 3151 \\
(3.61 \%) \\
\end{array}$ & $<0.05$ & $\begin{array}{l}7 / 3151 \\
(0.22 \%) \\
\end{array}$ & $>0.05$ \\
\hline \multicolumn{7}{|l|}{ No. of donation } \\
\hline First donation & $\begin{array}{l}51 / 104459 \\
(0.048 \%)\end{array}$ & $>0.05$ & $\begin{array}{l}1706 / 10445 \\
9 \\
(1.63 \%)\end{array}$ & $<0.05$ & $\begin{array}{l}19 / 10445 \\
9 \\
(0.018 \%)\end{array}$ & $>0.05$ \\
\hline Repeat donation & $\begin{array}{l}16 / 61350 \\
(0.026 \%)\end{array}$ & $>0.05$ & $\begin{array}{l}194 / 61350 \\
(0.31 \%)\end{array}$ & $>0.05$ & $\begin{array}{l}18 / 61350 \\
(0.029 \%)\end{array}$ & $>0.05$ \\
\hline
\end{tabular}

$\mathrm{P}<0.05$ is significant association between parameters

\section{Discussion}

Notable and significant waning drift of $H I V$ viral seroprevalence were observed in the phase of the study amongst blood donors in the present study. This finding is consistent with the noted declining trend and drift of $H I V$ seroprevalence in the general population in India ${ }^{8}$ and waning trend of $H I V$ prevalence amongst blood donors in India. $22-28$

$H I V$ and $H B V$ virus seroreactivity rate was significantly increased amongst first time donors in comparison to repeat blood donors in our study. This is in conformity with the previous studies. ${ }^{28-33} \mathrm{~A}$ significantly higher $\mathrm{HbsAg}$ seroprevalence was also reported in males than in females in the present study which is in consensus with other studies. ${ }^{29,34}$ There was higher prevalence of HbsAg donors in older than 35 years age groupin the study group which was similar to studies by Rodenas et al, ${ }^{35} \mathrm{Baba}$ et $\mathrm{al}^{36}$ and Ejele et al. ${ }^{37}$ This observation is bothersome as the most fruitful and economically viable age group of the community is affected. There is a necessity for improved amplification of preventive agenda expected at high risk behavioral change. ${ }^{29}$

In our study, the seroprevalence rate of $\mathrm{HCV}$ $(0.022 \%)$ was in concurrence with the rates ranging between 0 and $1.4 \%$ in the studies conducted in USA ${ }^{38}$ and Europe ${ }^{39}$ Nevertheless; it is lower than in the studies conducted in Ghana (2.8\%) and Port Harcourt $(2.9 \%) .^{40,41}$ The worldwide seroprevalence of $\mathrm{HCV}$ among blood donors varies from $0.4 \%$ to $19.2 \% .^{42}$

Similarly, the Seroprevalence of T.pallidum $(0.006 \%)$ in the present study is lower than the prevalence of $1.3 \%$ in Ethiopia ${ }^{33}$ and $3.6 \%$ in Maiduguri. ${ }^{43}$ In our study, none of the blood donors showed the existence of three or four TTI markers. Amid the blood donors with multiple infections, the $H I V-H B V$ co-infection donor rate was $6 / 14(42.85 \%)$, the HIV - syphilis co-infection was $1 / 14(7.14 \%)$, the $H B V-H C V$ co-infection was $4 / 14$ (28.58\%) and $H I V-$ $H C V$ co-infection was $3 / 14$ (21.43\%). This finding was comparable to the study conducted by Tessema et $\mathrm{al}^{33}$ and study published by Ejele et al. ${ }^{37}$ This high rate of TTI co-infection and the statistically significant relationship between $H I V \& H B V, H I V$ \& syphilis, $H B V$ \& $H C V$ and $H I V \& H C V$ infections may be due to the fact that these infectious agents share the common modes of transmission and risk groups. ${ }^{33,36,37}$

In the last decade, the sensitivity \& specificity of TTI screening tests had increased; thereby the viral infection transmission through blood products has been nearly eliminated in developed countries and has decreased in developing countries. 


\section{Conclusion}

A considerable proportion of the voluntary blood donors harbor transfusion-transmissible (TTI) infections. No vaccine exists to prevent TTI except $H B V$ infection, and treatment for $H I V \& H C V$ infection is costly. Sero-reactively negative window period of an infectious agent is still a hindrance to safe blood transfusion. Even the latest Nucleic acid amplification testing has its own pitfalls; therefore ensuring $100 \%$ voluntary blood donation with the time tested protocol of pre-donation counseling of probable blood donors with complete screening of donors' blood for TTI using prescribed standard methods are highly recommended to ensure the safety of blood for recipient. Periodic studies to investigate transfusion-transmissible infectious diseases along with emerging and reemerging infections are required to enable safe blood transfusion.

\section{References}

1. Directorate General of Health Services, Transfusion Medicine Technical Manual, second edition, 2003, page 383-4.

2. Busch MP. Transfusion-transmitted viral infections: Building bridges to transfusion medicine to reduce risks and understand epidemiology and pathogenesis. Transfusion 2006;46:1624-40.

3. Drugs and Cosmetics Rules, 1945 page 139: Schedule F, Parts XIIB and XIIC.

http://www.cdsco.nic.in/writereaddata/drugs\&cosmeticac t.pdf

4. Klein HG: Allogenic transfusion risk in the surgical patients. AMJ surg. 1995, 170:21-6.

5. Bisht A, Singh S, Marwaha N. Hemovigilance ProgramIndia. Asian J Transfus Sci. 2013;7:73-4.

6. Jain A, Kaur R. Hemovigilance and blood safety. Asian J Transfus Sci 2012;6:137-8.

7. Hemovigilance annual report (2001)

8. http://www.jrc.or.jp/vcms_lf/haemovigilanceannualreport 1993-2001.pdf.

9. NACO annual report (2015-16).

10. http://naco.gov.in/sites/default/files/HIV\%20Facts\%20\& \%20Figures.pdf

11. Malhotra S, Marwaha N, Saluja K. Seroprevalence of human immunodeficiency virus in north Indian blood donors using third and fourth generation Enzyme linked immunosorbent assay. Asian J Transfus Sci.2013;7(2):125-9.

12. Prevention of hepatitis B in India, An overview. World Health Organization. New Delhi 2002.

13. Finlayson MDC, Hayes PC and Simpson KJ: Diseases of the liver and biliary system: Hepatitis. Davidson's principles and practice of medicine. Edited by: Haslett C, Chilvers ER, Hunter JAA. 1999, Churchill Living stone, London, 706-15.

14. Patwari SI, Irshad M, Gandhi BM et al. Post transfusion hepatitis: A prospective study. Indian J Med Res.1986;84:508-12.

15. Fasola FA, Otegbayo IA: Post-transfusion hepatitis in sickle cell anaemia; retrospective-prospective analysis. Nig J Clin Pract. 2002,5:16-9.

16. Murray P, Rosenthal K, Kobayashi G, Pfaller M: Medical Microbiology. 2002, Mosby company, St.Loius, 379-80.
17. Pahuja S, Gupta SK, Pujani M, Jain M. Treponema pallidum hemagglutination assay seroreactivity among healthy Indian donors and its association with other transfusion transmitted diseases. Asian J Transfus Sci 2014;8:109-12.

18. Kitchen AD, Chiodini PL: Malaria and blood transfusion. Vox Sang. 2006, 90 (2):77-84.

19. Kitchen A, Mijovic A, Hewitt P: Transfusion-transmitted malaria: current donor selection guidelines are not sufficient. Vox Sang. 2005, 88 (3):200-1.

20. Purdy E, Perry E, Gorlin J, Jensen K: Transfusiontransmitted malaria: unpreventable by current donor exclusion guidelines? Transfusion. 2004,44(3):464-10.

21. Mungai M, Tegtmeier G, Chamberland M, Parise M: Transfusion-transmitted malaria in the United States from 1963 through 1999. N Engl J Med. 2001, 344 (26):19738.

22. Schlagenhauf $P$, Mueutener P. Imported malaria. In: Schlaenhauf $\mathrm{P}$, editor. Travellers' Malaria. Hamilton: BC Decker Inc; 2001:495-508.

23. Kinde G, Oke J, Gnahoui I, Massougbodji A: The risk of malaria transmission by blood transfusion at Cotonou, Benin. Sante. 2000, 10 (6):389-92.

24. Makroo RN, Saul P, Vashist RP, Shivial. Trends of HIV Infection in the Blood Donors of Delhi. Indian Journal of Pathology and Microbiology 1996;39:139-42.

25. Kapoor S. Singh R, Mittal A. Correlation of HIV infection and hepatitis B and syphilis. In: Aggarwal OP. Sharma AK, Indrayan A editors. HIV/AIDS Research in India. National AIDS Control Organization, Ministry of Health and Family Planning, Government of India, New Delhi; 1997. p. 465-68.

26. Khurana SB, Ram S. Seroprevalence of blood donors and patients for HIV during 1988 to March 1997 at Ludhiana Punjab: HIV/AIDS research in India / editors: Aggarwal OP, Sharma AK, Indrayan A: National AIDS Control Organization: New Delhi; 1998.p. 423-26.

27. Choudhury N, Ayagiri A, Ray VL. True HIV seroprevalence in Indian blood donors. Transfusion Medicine 2000;10:1-4.

28. Malhotra S, Marwaha N, Saluja K. Seroprevalence of human immunodeficiency virus in north Indian blood donors using third and fourth generation Enzyme linked immunosorbent assay. Asian J Transfus Sci 2013;7:1259

29. NACO study annual reports, National AIDS Control Organization. Annual Report NACO 20010-11. [Online]. Available from: URL: http://www.nacoonline.org.

30. Pahuja S, Sharma M, Baitha B, Jain M (2007) Prevalence and trends of markers of Hepatitis C Virus, Hepatitis B Virus and Human Immunodeficiency Virus in Delhi blood donors: A Hospital Based Study. Jpn J Infect Dis 60:389-91.

31. Singh K, Bhat S, Shastry S. Trend in seroprevalence of Hepatitis B virus infection among blood donors of coastal Karnataka, India. J Infect Dev Ctries2009;3(5):376-9.

32. Mathai J, Sulochana PV, Satyabhama S, Nair PK, Sivakumar S. Profile of transfusion transmissible infections and associated risk factors among blood donors of Kerala. Indian J Pathol Microbiol.2002;45:319-22.

33. Singh B, Kataria SP, Gupta R. Infectious markers in blood donors of East Delhi: prevalence and trends. Indian J Pathol Microbiol.2004;47:477-9.

34. Bhattacharya P, Chandra PK, Datta S, et al. Significant increase in $\mathrm{HBV}, \mathrm{HCV}$, HIV and syphilis infections among blood donors in West Bengal, Eastern India 20042005: Exploratory screening reveals high frequency of 
occult HBV infection. World J Gastroenterol. 2007;21:3730-3.

35. Tessema, B, Yismaw G, Kassu, A, Amsalu, A, Mulu A, Emmrich F et al. Seroprevalence of HIV, HBV, HCV and syphilis infections among blood donors at Gondar University Teaching Hospital, Northwest Ethiopia: declining trends over a period of five years. BMC Infect Dis. 2010;10:111.

36. Chandrasekaran S, Palaniappan N, Krishnan V, Mohan G, Chandrasekaran N. Relative prevalence of hepatitis B viral markers and hepatitis $\mathrm{C}$ virus antibodies (anti HCV) in Madurai, South India. Indian J Med Sci. 2000;54:2703.

37. Rodenas JG, Bacasen LC, Que ER. The prevalence of $\mathrm{HBsAg}(+)$ and anti $\mathrm{HCV}(+)$ among healthy blood donors at east avenue medical center, Quezon city. Phil J of Gastroenterology.2006;2:64-70.

38. Baba MM, Hassan AW, Gashau W: Prevalence of hepatitis B antigenaemia and human immunodeficiency virus in blood donors in Maidugiri, Nigeria. Niger J Med. 2000,9:10-12.

39. Ejele OA, Erhabor O, Nwauche CA: Trends in the prevalence of some transfusion-transmissible infections among blood donors in Port Harcourt, Nigeria. Haematology 2005, 8: 273-7.

40. Stevens CE, Taylor PE, Pindyck J: Epidemiology of Hepatitis C virus. J Am Med Assoc. 1997, 263:49-53.

41. Sharara AI, Hunt CM, Hamilton JD: Hepatitis C. Ann Intern Med. 1996, 125:658-8.

42. Wansbrough-Jones MH, Frimpong E, Cant B, Harris K, Evans MR, Teo CG: Prevalence and genotype of hepatitis $\mathrm{C}$ virus infection in pregnant women and blood donors in Ghana. Trans R Soc Trop Med Hyg. 1996, 92:496-9.

43. Koate BBD, Buseri FI, Jeremiah ZA: Seroprevalence of hepatitis $\mathrm{C}$ virus among blood donors in Rivers State, Nigeria. Transfus Med. 2005, 15:449-51.

44. Meena M, Jindal T, Hazarika A. Prevalence of hepatitis B virus and hepatitis $\mathrm{C}$ virus among blood donors at a tertiary care hospital in India: A five-year study. Transfusion 2011;51:198-202.

45. Chikwem JO, Mohammed I, Okara GC, Ukwandu NC, Ola TO: Prevalence of transmissible blood infections among blood donors at the University of Maiduguri Teaching Hospital, Maiduguri, Nigeria. East Afr Med J. 1997,4:213-6.

How to cite this article: Umesh $\mathrm{D}$, Aparna V, Padma S. Seroprevalence of transfusion-transmissible infectious agents (HIV, HBV, HCV, plasmodium species and treponema pallidum infections) among blood donors at a Tertiary Care Teaching Hospital in Chennai: Changing trends over a period of five years. India. Indian J Microbiol Res 2018;5(1):31-37 